\title{
ARTIKELEN
}

SERIE

\section{De democratische kwaliteit van gekozen en niet- gekozen vertegenwoordiging in gemeenten}

\author{
Hester van de Bovenkamp \& Hans Vollaard
}

\author{
Serie 'Lokale democratie doorgelicht' \\ Onder redactie van: Bas Denters \& Marcel Boogers
}

De vaak sombere analyses van democratische vertegenwoordiging op lokaal niveau zijn veelal gericht op problemen met partijen en verkiezingen. Directe participatie is geen goed alternatief, omdat alleen maar bepaalde, politiek toch vaak al actieve mensen daarvan gebruikmaken. Met het begrip 'vertegenwoordigingsclaim' laten we in twee kwalitatieve gevalstudies van de decentralisaties in het sociale domein echter zien dat er ook andere vertegenwoordigers dan gekozen politici zijn. Deze (zelf)benoemde, niet-gekozen vertegenwoordigers kunnen opkomen voor kwetsbare groepen die zich weinig politiek laten horen. Daarnaast toont ons onderzoek dat gekozen vertegenwoordigers zoals partijen en gemeenteraadsleden hun vertegenwoordigende rol kunnen versterken door: 1) beter samen te werken met niet-gekozen vertegenwoordigers, 2) hun vertegenwoordigingsclaims en de basis daarvan te expliciteren, en 3) hun responsiviteit naar de achterban te versterken door middel van andere autorisatie- en verantwoordingsstructuren dan verkiezingen. Op die manier is en kan democratische vertegenwoordiging in gemeenten sterker zijn dan de vaak sombere analyses doen vermoeden.

\section{Representatieve democratie herzien}

De kwaliteit van de lokale democratie kan rekenen op toenemende aandacht. Dit is mede het gevolg van de verschuiving van rijkstaken op het gebied van jeugdzorg, (arbeids)participatie en maatschappelijke ondersteuning naar gemeenten (Denters \& Boogers, 2016; Peters \& Van Stipdonk, 2016). Als gevolg daarvan worden hogere eisen gesteld aan de wijze waarop lokale democratie functioneert (Denters \& Boogers, 2016). Analyses van de lokale politiek in Nederland laten echter vaak geen positief beeld zien en leiden veelal tot de conclusie dat democratische vertegenwoordiging onder druk staat (Staatscommissie-Elzinga, 2000; Loots \& Peeters, 2013). Op het eerste gezicht lijkt er alle aanleiding voor deze conclusie. Zo klinken lokale wensen van burgers niet altijd even goed door in gemeenteraadsverkiezingen. Nationale politiek domineert immers de campagnes voor deze lokale verkiezingen. Daarnaast zijn, met de dalende verkiezingsopkom- 
sten, de wensen van niet-stemmers steeds minder te horen (Boogers \& Salomé, 2014). Politieke partijen, de belangrijkste spelers in gemeenteraadsverkiezingen en gemeenteraden, kampen ondertussen met een afkalvend ledenbestand (Den Ridder, 2014; Peters \& Van Stipdonk, 2016). Daardoor zijn ze niet alleen minder direct geworteld in de samenleving, maar blijven ze ook moeite houden om een representatieve afspiegeling van die samenleving te vormen (Peters \& Van Stipdonk, 2016). Ondertussen taant het vertrouwen van burgers in partijen en politici, ook op lokaal niveau (Den Ridder \& Dekker, 2015). Dit alles is extra problematisch nu gemeenteraden grotere verantwoordelijkheden hebben gekregen (Denters \& Boogers, 2016). Juist nu zouden ze goed moeten weten wat er leeft in de samenleving (Commissie Toekomstgericht Lokaal Bestuur, 2016; Fraanje, 2015). Bovengenoemde problemen rondom lokale verkiezingen zouden deels opgelost kunnen worden als raadsleden goede contacten onderhouden met de samenleving. In de praktijk zouden raadsleden echter te weinig tijd hebben voor volksvertegenwoordigende taken zoals persoonlijk contact met burgers en werkbezoeken (De Jager-de Lange e.a., 2014). In plaats daarvan zijn ze vooral druk met de machtsverhoudingen in het gemeentehuis, ook al dragen gemeenteraden met de dualisering van 2002 geen directe bestuurlijke verantwoordelijkheden meer (Van Ostaaijen, 2016; Rob, 2016: 19). Bovendien maken de regionale samenwerkingsverbanden die de gedecentraliseerde taken uitvoeren, het niet makkelijker voor individuele gemeenteraden om de belangen van burgers luid en duidelijk te laten doorklinken (vgl. Denters, 2015). Kortom, het lijkt bergafwaarts te gaan met democratische vertegenwoordiging op het lokale niveau.

Mede in reactie op bovenstaande probleemschets hebben burgers meer mogelijkheden gekregen om hun stem te laten horen dan alleen het uitbrengen van hun stem bij gemeenteraadsverkiezingen. Vooral sinds de jaren negentig van de vorige eeuw hebben gemeentebesturen ook intensievere participatievormen zoals interactieve beleidsvorming en referenda ingezet. Meer recentelijk zijn ook deliberatieve fora als G-1000 in zwang gekomen (Ministerie van BZK, 2015; Michels \& Binnema, 2016). Daarnaast krijgen burgers ook meer ruimte om zelf initiatieven te ontplooien, juist ook in het sociale domein (Rob, 2012; Tonkens e.a., 2015). Behalve bij sommige referenda is het aantal burgers dat op deze manier politiek participeert, echter beperkt (De Graaf e.a., 2016; Veldheer e.a., 2012; Peters e.a., 2014; Tonkens e.a., 2015; Michels \& Binnema, 2016). Bovendien blijkt keer op keer dat bij allerlei vormen van directe participatie goedgebekte hoogopgeleide blanke burgers van middelbare leeftijd oververtegenwoordigd zijn. Dat zijn dezelfde groepen die ook dominant zijn in gemeenteraden en partijen. Deze 'diplomademocratie' (Bovens \& Wille, 2011) kan ongelijkheid verder in de hand werken. Standpunten van mensen die wel en niet participeren, kunnen immers van elkaar verschillen, zeker op het vlak van ziektebeelden, werkperspectieven en gewenste vormen van welzijn en zorg (Bovens \& Wille, 2011; Den Ridder \& Dekker, 2015; Van de Bovenkamp \& Vollaard, 2015; Dekker e.a., 2016). Vooral kwetsbare groepen die niet geneigd zijn te participeren, zoals daklozen, mensen met psychiatrische problemen, probleemjongeren en dementerende ouderen, kunnen 
daarmee buiten beeld blijven. Directe participatie biedt dus weinig soelaas om de belangen van elke burger gelijk te laten meetellen.

Ongelijke directe participatie is geen probleem indien vertegenwoordigers ook de belangen behartigen van mensen die niet of nauwelijks politiek participeren. Bovengenoemde analyses geven echter weinig hoop dat dat in gemeentelijk Nederland te realiseren zou zijn. Het probleem van die analyses is evenwel dat die maar beperkt zicht bieden op de daadwerkelijke vertegenwoordigingspraktijk op lokaal niveau. Allereerst zijn ze vaak slechts gebaseerd op enquêtes onder raadsleden en griffiers. Daarnaast wordt vertegenwoordiging veelal verengd tot een kwestie van verkiezingen en gemeenteraadsleden die al dan niet tijd hebben om contact te onderhouden met andere burgers (zie ook Van der Zee, 2013). In de politieke filosofie is echter recent het begrip 'vertegenwoordigingsclaim' geïntroduceerd, waarmee een veelzijdiger beeld van vertegenwoordiging kan worden verkregen (Saward, 2010). Dit geldt zowel voor wie er allemaal als vertegenwoordigers optreden (naast gekozen politici kunnen dit ook zelfbenoemde vertegenwoordigers zijn) als voor de manier waarop zij hun claims autoriseren en verantwoorden (naast verkiezingen kunnen dit ook allerlei andere contacten met burgers zijn). Door deze veelzijdigheid in beeld te brengen zou het zorgelijke oordeel over de lokale vertegenwoordiging anders kunnen uitvallen dan de bovengenoemde probleemschets. Er is, zeker op lokaal niveau, nog weinig empirisch onderzoek dat onderzoek doet met behulp van het concept vertegenwoordigingsclaim om zo inzicht te krijgen in de gevarieerde vertegenwoordigingspraktijk. In dit artikel presenteren we gevalstudies van democratische vertegenwoordiging bij de recente grootschalige decentralisaties van jeugdzorg, (arbeids)participatie en maatschappelijke ondersteuning, gebruikmakend van het concept vertegenwoordigingsclaim. Het zijn vooral de eerdergenoemde kwetsbare burgers, die vaak niet geneigd zijn zelf hun stem te laten horen, die met de consequenties van de decentralisaties te maken hebben. Dit maakt de decentralisaties een uitgelezen casus om democratische vertegenwoordiging op lokaal niveau te onderzoeken. Voorafgaand aan de resultaten uit ons onderzoek staan we in dit artikel eerst stil bij het begrip vertegenwoordigingsclaim en de gebruikte onderzoeksmethoden.

\section{Een veelzijdige vertegenwoordigingspraktijk}

Democratische vertegenwoordiging behelst een variëteit aan activiteiten van verschillende mensen en groepen, zo stelde Hannah Pitkin al lang geleden in haar vermaarde boek The concept of representation (Pitkin, 1967). De literatuur over democratische vertegenwoordiging focust echter vooral op gekozen vertegenwoordiging. In discussies over dit thema hebben vooral (problemen met) verkiezingen en politieke partijen centraal gestaan. Vanaf het begin van de jaren negentig is de dalende opkomst bij verkiezingen, zeker op lokaal niveau, mede aanleiding geweest voor discussies over een kloof tussen burger en politiek (zie Irwin \& Van Holsteyn, 2002). Met een dalend aantal partijleden en grotere afhankelijkheid van overheidssubsidies zouden partijen niet langer de politieke voorhoede 
zijn van maatschappelijke krachten, maar steeds meer onderdeel van het staatsapparaat zijn geworden (Mair, 2005). Het partijledenbestand is bovendien weinig representatief voor de samenleving met een oververtegenwoordiging van hoger opgeleide oudere mannen (Den Ridder, 2014: 59). Daardoor kunnen partijen minder makkelijk raadsleden rekruteren die een afspiegeling vormen van de samenleving. Partijen zijn verder minder belangrijk geworden als intermediair tussen kiezers en overheid, doordat functies als socialisatie en communicatie deels door onderwijs en media zijn overgenomen. De vraag of partijen overbodig zijn geworden, wordt daarom met enige regelmaat gesteld (De Lange e.a., 2012).

De vertegenwoordigingspraktijk is echter veelzijdiger dan verkiezingen en partijen alleen. Met het begrip 'vertegenwoordigingsclaim' is er in de politieke filosofie recentelijk al meer oog gekomen voor een andersoortige vertegenwoordiging (Rehfeld, 2006; Saward, 2010; Severs, 2010; Maia, 2012; Montanaro, 2012). Er is echter nog maar weinig empirisch onderzoek naar gedaan. Er zijn natuurlijk wel studies van belangengroepen, maar die richten zich meer op hun (strategieën voor) beleidsinvloed dan vertegenwoordiging van de achterban (Saward, 2010; Wolff, 2013). Bovendien zijn er naast belangengroepen nog allerlei andere actoren actief die een vertegenwoordigende rol kunnen spelen. Deze zelfbenoemde vertegenwoordigers zijn nog beperkt in beeld gebracht, zeker op het lokale niveau. Het begrip vertegenwoordigingsclaim biedt de mogelijkheid om meer inzicht te krijgen in deze andere vormen van vertegenwoordiging. Via deze invalshoek is elke actor die zichzelf als vertegenwoordiger van een bepaalde groep of van een bepaald belang presenteert aan een zeker publiek, te beschouwen als een vertegenwoordiger (De Wilde, 2013). Zo kunnen bijvoorbeeld kerken claimen christenen te vertegenwoordigen, milieuorganisaties zich opwerpen als vertegenwoordiger van toekomstige generaties, en artsen claimen op te komen voor hun patiënten (Saward, 2009, 2010). In de literatuur worden niet-gekozen vertegenwoordigers gezien als kanaal om de belangen van groepen die zelf hun stem niet (kunnen) laten horen, te laten doorklinken (Saward, 2010). Zij kunnen daarmee ongelijkheid tegengaan die is ontstaan door gekozen vertegenwoordiging en directe participatie. Niet-gekozen vertegenwoordigers, zoals in onze casus huisartsen of ouderenbonden, zouden ook op meer vertrouwen van burgers kunnen rekenen dan gekozen politici, omdat zij niet direct onderdeel uitmaken van het politiek apparaat (Saward, 2010). Daarmee zouden ze ook een bijdrage kunnen leveren aan het vertrouwen onder burgers dat hun belangen worden gehoord in het politieke bestel. Zo zou meer oog voor niet-gekozen vertegenwoordiging aanleiding kunnen zijn de toch vaak sombere analyses over representatieve democratie te herzien, en andere oplossingen voor eventuele problemen aan te dragen.

Het begrip vertegenwoordigingsclaim richt de aandacht bovendien op andere rechtvaardigingsgronden voor deze claims dan formele verkiezingen. Een vertegenwoordiger kan zich ook beroepen op een gemeenschappelijke identiteit, expertise of gedeelde ervaringen. In het publieke debat, of dat nu in de media, in de gemeenteraad of ergens anders plaatsvindt, kunnen die claims van vertegenwoordigers worden geuit, vervolgens getoetst en dan al dan niet geaccepteerd door 
hun (zelf gedefinieerde) achterban, andere vertegenwoordigers en uiteindelijk door formele besluitvormers. Een geaccepteerde vertegenwoordigingsclaim is echter niet per definitie ook een democratische claim (Rehfeld, 2006). Om de democratische kwaliteit van vertegenwoordiging te bepalen letten we in dit artikel op twee aspecten. Ten eerste moet de vertegenwoordiger niet zomaar zijn eigen gang kunnen gaan. Er zal sprake moeten zijn van responsiviteit in de relatie tussen vertegenwoordiger en het (deel van het) volk waarvoor hij of zij claimt op te komen. Ten tweede gebruiken we het criterium van gelijkheid om de praktijk te toetsen aan het ideaal dat elke burger evenveel meetelt in de besluiten over de politieke gemeenschap.

Responsiviteit wordt in dit artikel geconceptualiseerd in termen van (a) autorisatie: selectie of sturing van de vertegenwoordigers, en (b) verantwoording: de uitleg door een vertegenwoordiger aan de achterban over zijn handelen (Urbinati \& Warren, 2008; Maia, 2012; Montanaro, 2012). Naast verkiezingen zijn er ook andere vormen van autorisatie en verantwoording (Urbinati \& Warren, 2008; Severs, 2010; Montanaro, 2012). Voor wat betreft autorisatie valt daarbij te denken aan instemming betuigen via het tekenen van een petitie of het schrijven van een ingezonden brief, een melding doen bij een meldpunt, het meedoen aan door de vertegenwoordiger georganiseerde protestmarsen, of het aanmelden of afmelden als lid van een vertegenwoordigende organisatie. Het verantwoorden van de claims aan de achterban kan plaatsvinden in de media en door het beschikbaar maken van documenten als jaarverslagen en adviezen aan besluitvormers op websites en via nieuwsbrieven (Montanaro, 2012). Autorisatie en verantwoording richten zich op de relatie tussen vertegenwoordigers en degenen die zij claimen te vertegenwoordigen. Voor het toetsen van de democratische kwaliteit van vertegenwoordiging in gemeenten is daarnaast het punt van gelijkheid van belang. Het gaat dan om de vraag of ongelijkheden in de belangenbehartiging van allerlei groepen, bijvoorbeeld ontstaan door ongelijke deelname aan participatie, (deels) worden gecompenseerd door gekozen en niet-gekozen vertegenwoordigers (Montanaro, 2012).

In de volgende paragraaf wordt uitgelegd welke methoden zijn gebruikt om gekozen en niet-gekozen vertegenwoordiging en de democratische kwaliteit daarvan te onderzoeken.

\section{Methoden}

Er is nog maar weinig empirisch onderzoek gedaan naar niet-gekozen vertegenwoordiging en democratische kwaliteit. In zo'n exploratieve fase van het onderzoek zijn kwalitatieve gevalstudies de aangewezen weg om na te gaan hoe nietgekozen vertegenwoordiging eigenlijk vorm krijgt. Bovendien bieden dergelijke gevalstudies de mogelijkheid om een diepgaander beeld te krijgen van de lokale vertegenwoordigingspraktijk dan enquêtes. We hebben ons in die studies gericht op de decentralisaties van jeugdzorg, (arbeids)participatie en maatschappelijke ondersteuning per 1 januari 2015. Juist omdat deze decentralisaties het sociale 
domein betroffen, was de verwachting dat daar in ieder geval niet-gekozen vertegenwoordigers die claimen op te komen voor allerlei kwetsbare groepen een rol zouden spelen. Om een zo gevarieerd beeld te verkrijgen van mogelijke vormen van vertegenwoordiging hebben we studies verricht in twee gemeenten die tamelijk sterk van elkaar verschilden qua geografisch karakter, opleidingsniveau, arbeidsperspectieven en ziekten onder de bevolking: een middelgrote universiteitsstad in de Randstad en een fusiegemeente in het noordelijke krimpgebied van het land.

We hebben ons onderzoek uitgevoerd in de periode herfst 2013 tot en met zomer 2015. We hebben verschillende kwalitatieve methoden gebruikt. Ten eerste hebben we relevante documenten, zoals beleidsplannen, verslagen van gemeentelijke consultatierondes, gemeenteraadsnotulen, adviezen van adviesorganen en verslagen van organisaties die claimen voor burgers op te komen, onder de loep genomen. Ook hebben we geschreven lokale media geanalyseerd om te kijken welke actoren daarin vertegenwoordigingsclaims maakten. Daarnaast zijn websites van de geïdentificeerde vertegenwoordigers onderzocht. Ten tweede hebben we 34 actoren die actief waren op het gebied van de decentralisaties in de twee gemeenten, geïdentificeerd op basis van bovengenoemde documentanalyse, geïnterviewd. Onze respondentengroep bestond uit: 3 wethouders, 2 ambtenaren, een adviseur van de gemeente op het gebied van burgerparticipatie, 7 gemeenteraadsleden, 8 vertegenwoordigers van patiënten-, ouderen- en mantelzorgersorganisaties, 6 leden van adviesraden, 5 zorgprofessionals, een lokale journalist en een directeur van een sociale werkplaats. Wethouders en beleidsmedewerkers vroegen we naar de activiteiten die ze hadden ondernomen om met patiënten en cliënten en vertegenwoordigers in contact te komen, welke claims ze accepteerden, met welke vertegenwoordigers ze contact hadden gehad en wat hun ervaringen daarmee waren. Respondenten die als vertegenwoordigers actief waren in het decentralisatiedebat, vroegen we wie zij in het debat vertegenwoordigden, op basis waarvan ze die claims maakten, welke autorisatie- en verantwoordingskanalen zij gebruikten, wat hun ervaringen waren met vertegenwoordiging, welke andere actoren zij als vertegenwoordiger zagen en welke contacten ze met andere vertegenwoordigers onderhielden. Van de interviews zijn geluidsopnamen gemaakt, die vervolgens woordelijk zijn uitgeschreven.

We hebben de data geanalyseerd aan de hand van de volgende thema's: (1) welke actoren vertegenwoordigingsclaims (zouden kunnen) maken; (2) voor welke al dan niet zelf gedefinieerde achterban zij dat hebben gedaan; (3) welke argumenten actoren hebben aangevoerd als rechtvaardiging voor hun claims; (4) op welke manier die actoren hun claims kenbaar hebben gemaakt bij hun achterban, andere vertegenwoordigers en de formele besluitvormers (in casu de gemeenteraad en het college van burgemeester en wethouders); (5) de acceptatie van de claims door andere vertegenwoordigers en de formele besluitvormers en de redenen daarvoor; (6) vormen van autorisatie en verantwoording die de vertegenwoordigers hebben gebruikt en hun ervaringen daarmee (om te toetsen op responsiviteit); (7) of bepaalde groepen buiten beeld zijn gebleven met het oog op 
gelijkheid; (8) en de manier waarop de verschillende gekozen en niet-gekozen vertegenwoordigers contact met elkaar hadden en hun ervaringen daarmee.

De volgende paragrafen beschrijven het beeld van de democratische kwaliteit van gekozen en niet-gekozen vertegenwoordiging dat oprees in beide gemeenten.

\section{Resultaten}

In deze paragraaf beschrijven we eerst gekozen en niet-gekozen vertegenwoordigers in termen van autorisatie, verantwoording en gelijkheid en vervolgens gaan we in op de interacties tussen gekozen en niet-gekozen vertegenwoordigers.

\subsection{Gekozen vertegenwoordigers bij de decentralisaties}

Autorisatie en verantwoording van gekozen vertegenwoordigers, in onze casus de gemeenteraadsleden, gebeuren in de eerste plaats door middel van verkiezingen. Wat verkiezingen betreft is het beeld niet rooskleurig. Lokale verkiezingen hebben te maken met een dalende opkomst. In 2014 kwam gemiddeld 54\% van de kiesgerechtigden op. In de twee door ons onderzochte gemeenten lag de opkomst rond dit gemiddelde. Een aanvullend probleem is, zoals eerder vermeld, dat lokale verkiezingen veelal door nationale, in plaats van lokale, vraagstukken worden gedreven (Schaap, 2015: 36). Dit maakt dat de invulling van het gedecentraliseerde beleid in de gemeente niet centraal stond in de campagne. Bovendien is eerder al geconstateerd dat veel raadsleden kennis over het decentralisatiebeleid ontberen. Dit belemmert hen om hun vertegenwoordigende rol te spelen (Loots \& Peeters, 2013; Rob, 2013; Van den Berg, 2013).

Hoewel onze respondenten bovenstaande problemen herkennen, komt uit onze casussen een gevarieerd beeld van responsiviteit naar voren, dat ook positieve elementen kent. Gemeenteraadsleden baseren hun vertegenwoordigende claim niet alleen op verkiezingen. Ze autoriseren zich op het gebied van de decentralisaties door bijvoorbeeld werkbezoeken af te leggen aan zorgorganisaties en sociale werkplaatsen. Op deze manier proberen ze kennis van zaken op te bouwen, die als basis kan dienen van hun claims. Ook organiseert een aantal van de raadsleden digitale contactpunten of inloopspreekuren of is herkenbaar aanwezig op straat zodat burgers hen kunnen benaderen. Op deze manier kunnen burgers sturing aan hun vertegenwoordigers geven. In kleine gemeenten is daarbij het voordeel dat raadsleden vaak bekend zijn en zij ook tijdens hun dagelijkse doen en laten, kunnen worden aangesproken door burgers. Een voormalig en voorzitter van een adviesraad sociale zaken merkt op: 'Als ik een wandeling maak of ik maak een fietstochtje hier rondom, dat is dan zeg 10 kilometer wat je normaal in een half uur, drie kwartier ofzo fietst. Dan ben ik een halve dag onderweg.'

Er zijn ook raadsleden die zelf werkzaam zijn in de zorg of gebruikmaken van de zorg en gebruik kunnen maken van hun professionele of gebruikerservaringen in het raadswerk: 'De arrogantie van de instituten waar we tegenaan blijven lopen. Echt ongelofelijk. En dan is het handig dat je daar zelf een paar jaar als cliënt hebt gelopen.' 
De respondenten vertelden dat lang niet alle raadsleden zo actief zijn om in contact te kunnen komen met hun achterban of van eigen ervaringen gebruik te kunnen maken. Er lijken wat dat betreft grote verschillen te bestaan tussen raadsleden. Dit heeft onder andere met de taakopvatting van raadsleden te maken. In de woorden van een gemeenteraadslid: 'Ze [collega-raadsleden] vonden ook dat dat niet ... dat proefde ik vorige keer nog in de commissievergadering, vonden dat ook niet hun taak. Zo van, we zijn kaderstellend en al die individuele verhalen zijn toch niet meer de kaders en de grote lijnen? Terwijl ik denk: "Ik kan die grote lijnen alleen maar maken als $i k$ de verhalen daaronder weet en weet waar ik het over heb, dan kan ik kaders stellen. Dus ik heb die informatie nodig." En zij vinden dat veel te veel detailwerk. Dus het is ook wel gewoon een principiële opvatting van hoe je je raadswerk doet.'

Deze verschillen in taakopvattingen komen niet zonder meer overeen met de klassieke discussies over of raadsleden vooral vertrouwenspersonen (trustees), partijsoldaten of spreekbuis van de achterban dienen te zijn (zie o.m. Karlsson, 2013). Het komt in dit geval meer op de vraag neer of gemeenteraadsleden überhaupt bereid zijn buiten het gemeentehuis verdere informatie te verwerven.

Verantwoording behelst net als autorisatie meer dan verkiezingen alleen. Raadsvergaderingen zijn openbaar en kunnen vaak worden bekeken via internet. Daar zijn soms ook de notulen van de raadsvergaderingen te vinden. In beide gemeenten is er daarnaast nog lokale pers aanwezig die aandacht besteedt aan raadsvergaderingen. Lokale media zijn echter aan het verdwijnen, wat de transparantie en daarmee de publieke verantwoording van de lokale politiek onder druk zet (Stimuleringsfonds voor de Pers, 2012). Burgers kunnen hun raadsleden ook zelf aanspreken op hun functioneren, maar dit gebeurt volgens respondenten slechts sporadisch. Volgens hen zijn burgers maar beperkt geïnteresseerd in verantwoording. Een raadslid verwoordde deze desinteresse als volgt: 'Mensen haken eerder af dan dat ze die verantwoording komen halen.'

Gelijkheid is naast responsiviteit het andere criterium waar we in dit artikel vertegenwoordiging mee beoordelen. We zagen in de inleiding dat wat gelijkheid betreft er een aantal problemen speelt met het gekozen vertegenwoordigingskanaal. Zo komen laagopgeleiden minder op bij verkiezingen en laten ze zich minder zien bij bijvoorbeeld inspraakavonden dan hoogopgeleiden (Bovens \& Wille, 2011). Dit is vooral bij de decentralisaties problematisch aangezien lager opgeleiden meer gebruikmaken van voorzieningen die nu onder de verantwoordelijkheid van de gemeenten vallen (SCP, 2015; Tonkens e.a., 2015). Sommige raadsleden uit de door ons onderzochte gemeenten gaan daarom gericht naar mensen die onzichtbaar dreigen te blijven toe. Een raadslid zegt hierover: 'We proberen (...) naast die contacten met die dorpsbelangen ook aan te bellen bij de mensen die nergens op afkomen. Want er zijn ook mensen die niet naar zo'n bijeenkomst [van de wijkvereniging] gaan en dan hoor je alleen als je naar zo'n bijeenkomst gaat de mensen die, nou ja, het hoogste woord voeren. Is dat goed als politieke partij om daar achteraan te gaan? Of niet achteraan te gaan, maar je moet eigenlijk wel een goede afspiegeling hebben van het hele dorp dan hè?' 
Ook voor raadsleden die veel moeite doen om in contact te komen met de achterban, blijven bepaalde groepen echter buiten beeld. In de woorden van een gemeenteraadslid: 'Allochtonen en GGZ-problematiek. Je krijgt echt niemand die daar iets over hè vanuit die doelgroep zal zeggen. Want dat, dat hebben zij niet, dat bestaat niet. Dus als je via de kanalen wanneer normaal iets wat met allochtonen zou spelen zou bevragen, dan vang ik daar meteen bot.'

We concluderen dat het kanaal van gekozen vertegenwoordiging kampt met een aantal problemen. We zagen echter ook dat vertegenwoordigende claims van raadsleden niet alleen gebaseerd zijn op verkiezingen, en dat er grote verschillen bestaan in de mate waarin raadsleden responsief zijn naar de achterban.

\subsection{Niet-gekozen vertegenwoordigers bij de decentralisaties}

Binnen gemeenten is naast gekozen vertegenwoordigers ook een grote groep nietgekozen vertegenwoordigers actief. Deze niet-gekozen vertegenwoordigers claimen groepen burgers te vertegenwoordigen die met de decentralisaties te maken hebben. Daarnaast noemden onze respondenten een aantal potentiële vertegenwoordigers die nu nog geen vertegenwoordigende rol spelen maar dat in de toekomst wel zouden kunnen doen. Er bestaat een brede variëteit aan actoren binnen de groep van niet-gekozen vertegenwoordigers (Balinski \& Young, 2010; Van de Bovenkamp \& Vollaard, 2015). Zo zijn er vertegenwoordigers die formeel zijn aangewezen als vertegenwoordiger. In het geval van de decentralisaties zijn dit de adviesraden zoals de Wmo-adviesraden en adviesraden op het gebied van sociale zaken. Daarnaast bestaat er een groep niet-gekozen zelfbenoemde vertegenwoordigers. Deze groep bestaat onder andere uit lokale patiëntenorganisaties, ouderenorganisaties, zorgprofessionals, kerken en buurtverenigingen.

Ook niet-gekozen vertegenwoordigers kennen verschillende mechanismen die hen autoriseren een vertegenwoordigende rol te spelen. Dit kunnen dagelijkse contacten met de achterban zijn, wat bijvoorbeeld voor zorgprofessionals, directeuren van sociale werkplaatsen en kerken geldt. Anderen beroepen zich op eigen ervaringen als cliënt. Het belang van het laatste wordt onderstreept door een voorzitter van een adviesraad op het gebied van sociale zaken: 'Omdat zij de ervaring hebben en als je aan de andere kant zit dan begrijp je vast niet hoe de belevingswereld is van de cliënt zelf.'

Anderen leunen naast ervaringsdeskundigheid op verschillende contacten met hun achterban. Daarbij valt te denken aan het organiseren van bijeenkomsten met de achterban, werkbezoeken, contactpunten, polls et cetera. Deze contacten zijn bedoeld om te weten wat de achterban belangrijk vindt. De voorzitter van een mantelzorgorganisatie zegt hierover: 'Want we weten ook wel dat de valkuil van een bestuur kan zijn dat je hele interessante bijeenkomsten meemaakt en leuke dingen zegt, maar dat je je voeling verliest met de mensen waar het om gaat, dus dat is voor ons wel (...) heel erg belangrijk dat we die mantelzorgers horen. Dat we het contact met hen houden.' 
Wmo-adviesraden kiezen veelal voor een gelaagde vertegenwoordigingsstructuur. Leden van de adviesraad zijn vaak ook actief in bijvoorbeeld patiëntenorganisaties of huurdersverenigingen. Op deze manier kunnen zij contact opnemen met de leden van deze organisaties voordat een advies geformuleerd wordt. Zo kunnen ze ervoor zorgen dat dit advies wordt ondersteund door de achterban. Hoewel dit in theorie goed geregeld is, blijkt de praktijk weerbarstiger. De voorzitter van een Wmo-adviesraad zegt hierover: 'Niet iedereen die daar zit [in de adviesraad] heeft een even centrale functie in de organisatie waar die zit. Niet iedereen, en niet alleen door zichzelf, maar ook door het tempo waarin dingen gebeuren, heeft de tijd. Waar wij [als raad] eens in de maand vergaderen, [vergaderen] zij [in de organisatie] misschien eens in de twee maanden. En dan komt er een Wmo-beleidsplan dat zes weken inspraak kent, dan komt er dus van de theorie [van achterbanraadpleging] niets terecht. Zij slagen er dan niet in om terug te koppelen naar de achterban (...). Het komt erop neer dat ervaringsdeskundigen op basis van gezond boerenverstand met kennis van de doelgroep, dat wel, maar niet met directe terugkoppeling, (...) bijna op persoonlijke titel inbreng heeft in het geheel.'

Niet-gekozen vertegenwoordigers leggen op verschillende manieren verantwoording af, bijvoorbeeld door notulen van vergaderingen en jaarverslagen openbaar te maken, bijeenkomsten te organiseren met hun achterban, nieuwsbrieven te verspreiden en via berichten in de media. Ook niet-gekozen vertegenwoordigers kampen echter met het probleem dat de achterban maar beperkt interesse toont in verantwoordingsactiviteiten. Bovendien is veel van het vertegenwoordigingswerk van niet-gekozen vertegenwoordigers informeel van aard. De adviesraden hebben bijvoorbeeld vaak informeel contact met wethouders en ambtenaren. Dit biedt de mogelijkheid het beleid al in een vroeg stadium te beïnvloeden maar tegelijkertijd wordt het lastig om verantwoording af te leggen. In de woorden van een lid van de Wmo-adviesraad: 'Als een gevraagd advies tot stand is gekomen, dan is er zoveel aan vooraf gegaan. Dat is voor niemand zichtbaar.'

Respondenten benadrukken dat niet-gekozen vertegenwoordigers een belangrijk kanaal zijn om groepen burgers te horen die te maken hebben met de decentralisaties, maar die buiten beeld dreigen te raken bij formele participatie- en vertegenwoordigingskanalen. Ze kunnen daarmee een belangrijke bijdrage leveren aan het criterium gelijkheid. Sommigen doen dat door de keuze te maken cliënten zelf aan het woord te laten, anderen door specifiek op te komen voor kwetsbare groepen zoals laaggeletterden, daklozen of bepaalde groepen niet-westerse migranten. Tegelijkertijd realiseren respondenten zich dat er ook bij hen altijd hiaten blijven bestaan. Een voormalig voorzitter Wmo-adviesraad zegt hierover: 'Als patiënt heb $i k$ heel veel contact met medekneuzen. I $k$ heb heel veel contact met dak- en thuislozen, omdat ik daar, daar doe ik dus ook wat vrijwilligerswerk. Maar ik heb geen illusie dat je het haalt. Dat je écht alles weet.'

Vooral professionals en kerken worden in staat geacht op te komen voor groepen die anders buiten beeld dreigen te blijven aangezien zij 'in de frontlinie' staan, bij mensen thuis komen en daar zien wat er misgaat. Hoewel kerken en professionals nog maar beperkt een vertegenwoordigende rol spelen op het lokale niveau, zien 
respondenten daartoe wel potentieel. ${ }^{1}$ De voorzitter van de Wmo-adviesraad licht dit toe: 'Het [de kerk] is een van de weinige organisaties die bij hoog en laag binnenkomen. En ook een van de weinige organisaties die ook echt bij mensen binnenkomt. Ik bedoel meestal heeft een kerk bezoekwerk wel redelijk geregeld. Je komt bij mensen over de vloer en ziet wat er leeft (...). Dus het is wel een van de organisaties die bij uitstek misschien ook wel het eerste het [problemen] in beeld kan brengen, ja.'

Professionals hebben door dagelijks contact met patiënten een beeld van de problemen die zich voordoen in de praktijk: 'Wij moeten ons dagelijks zien te redden en daarbij hebben we nu een praktijkondersteuner GGZ (...) aangesteld. Om de lichte psychische hulp op te vangen. Maar langzaamaan kraakt dat in de voegen ook wel een beetje, want ja, er komt eigenlijk steeds meer aanbod, omdat de wachttijden in de reguliere GGZ door de transities langzaam steeds meer oplopen. Dus bij ons in de praktijk hebben we al een wachttijd van twee, drie weken daardoor. Er zijn heel veel mensen die psychische hulp nodig hebben. En daarnaast krijgen we ook heel vaak vragen over WMO waar het mensen gewoon niet duidelijk is waar ze terecht moeten. En dan verwijzen wij naar het gemeenteloket. (...). Ik merk wel dat er steeds meer zorgmijders zijn. Mensen die bepaalde vormen van zorg niet willen vanwege eigen risico of transities. En dat zijn met name de sociaal zwakkere mensen die eigenlijk altijd eerst vragen van gaat mij dat geld kosten. Dus dat is ook een belangrijke ontwikkeling denk ik.'

Niet-gekozen vertegenwoordigers kunnen ook optreden als intermediair tussen gemeenten en groepen die voor de gemeente moeilijk te bereiken zijn. Jongeren die gebruikmaken van jeugdzorg, zijn daar een voorbeeld van: 'Ik moet die met dat petje die daar loopt die moet ik hebben. Wat wil jij eigenlijk? Die bereik ik niet. Die denken: doei', aldus een van de geïnterviewde wethouders. Regionale patiëntenorganisaties proberen gemeenten in contact te brengen met dit soort groepen, bijvoorbeeld door gebruik te maken van methoden die aansluiten bij de leefwereld van deze jongeren, zoals het maken van filmpjes over de dingen die zij belangrijk vinden in de zorg.

Bovenstaande beschrijving laat zien dat niet-gekozen vertegenwoordiging gevarieerd is in termen van responsiviteit. Daarnaast kunnen niet-gekozen vertegenwoordigers een diversiteit aan groepen vertegenwoordigen, waardoor ze kunnen bijdragen aan het democratisch ideaal van gelijkheid.

\subsection{Gekozen en niet-gekozen vertegenwoordigers als aanvullende kanalen}

In deze paragraaf laten we zien hoe gekozen en niet-gekozen vertegenwoordiging elkaar versterken. Ten eerste kan dit door het delen van informatie. Niet-gekozen vertegenwoordigers kunnen gekozen vertegenwoordigers specifieke informatie verschaffen die zij kunnen gebruiken in hun raadswerk. Verkiezingen leveren immers niet direct informatie op over wat precies de inhoudelijke voorkeuren zijn van kiezers, zeker nu kiezers minder opkomen en partijen minder in de maat-

1 Zorgprofessionals doen dat wel op het nationale niveau, onder andere in georganiseerd verband (Van de Bovenkamp \& Vollaard, 2015). Op het lokale niveau lijkt deze organisatie veelal te ontbreken. 
schappij geworteld zijn (Wolff, 2013: 4-5). Zoals eerder is aangegeven, bestaat er onder raadsleden bovendien een gebrek aan kennis over de decentralisaties. Contacten met niet-gekozen vertegenwoordigers kunnen helpen dit kennishiaat weg te werken volgens een raadslid: 'De vorige voorzitter van de WMO-adviesraad daar belde ik bij wijze van spreken wekelijks mee, dus informeel is daar heel veel contact geweest. (...) Omdat zij natuurlijk ook vaak zo snel wisten oh dat moet je daar eens proberen (...) en wij hebben dit en dit gehoord. Dat je elkaar heel erg op de hoogte kon houden van informatie en wat er aan het gebeuren was en bij wie je dan moest zijn.'

Andersom kan de institutionele positie van de gemeenteraad reden zijn voor nietgekozen vertegenwoordigers om raadsleden te benaderen om invloed uit te oefenen op het college. Hierover zegt een medewerker van een cliëntenorganisatie: 'Het heeft meer impact als de gemeenteraad het zegt. Het is voor die gemeenteraadsleden handig, want die hebben ineens veel meer munitie om mee te schieten. Ik denk dat je op die manier ook invloed kan hebben.'

In termen van de groepen die vertegenwoordigers claimen te vertegenwoordigen, vullen de verschillende kanalen elkaar ook aan. Zoals we in de vorige paragraaf lieten zien, kunnen niet-gekozen vertegenwoordigers ongelijkheid tegengaan door op te komen voor groepen die anders buiten beeld dreigen te raken. Ze doen dat met een beroep op eigen ervaringen, professionele kennis of contacten met groepen die gebruikmaken van gemeentelijke diensten. Op deze manier kunnen zij aandacht vragen voor specifieke groepen die te maken hebben met de decentralisaties en die mogelijk buiten beeld blijven bij gekozen vertegenwoordigers. Daarnaast kunnen niet-gekozen vertegenwoordigers het vertrouwen genieten van burgers die het vertrouwen in overheid en politiek verloren hebben: 'Het is nu al een continue strijd met wisselende heftigheid, maar om naar de burgerij toe aan te geven dat wij in principe een onafhankelijke organisatie zijn. Want heel veel mensen vertrouwen eigenlijk niks meer (...). Daar zit geen vertrouwen in de overheid, bij heel veel mensen niet.'

Ook gekozen vertegenwoordigers komen op voor specifieke groepen. Als lid van de gemeenteraad besluiten zij echter ook formeel over voorstellen voor de gehele gemeenschap. Veel raadsleden beschouwen de gehele gemeenschap ook als belangrijkste object van vertegenwoordiging (Karlsson, 2013: 103). Raadsleden kunnen dus de belangenbehartiging van specifieke groepen aanvullen door diverse belangen tegen elkaar af te wegen met het oog op het algemene belang van de gehele gemeenschap (Wolff, 2013; Rob, 2016: 25). Ook in die zin kunnen de vertegenwoordigers gezien worden als aanvullende kanalen. De gemeenteraad kan het platform zijn waar verschillende wensen en verlangens, door zowel gekozen als niet-gekozen vertegenwoordigers, kenbaar kunnen worden gemaakt. Het is ook de plek waar er prioriteiten tussen die wensen en verlangens kunnen worden gesteld.

\subsection{Gekozen en niet-gekozen vertegenwoordigers als tegenwerkende kanalen}

Hoewel er verschillende manieren zijn waarop gekozen en niet-gekozen vertegenwoordiging elkaar kunnen aanvullen, gaan ze in de praktijk niet altijd probleem- 
loos samen. Niet-gekozen vertegenwoordigers hebben soms wel contact met leden van de gemeenteraad maar richten zich voornamelijk direct op het college. Dit geldt natuurlijk vooral voor de adviesraden die een formele positie hebben ten opzichte van het college. Dit leidt er in de praktijk toe dat adviesraden vaak eerder betrokken zijn bij beleidsvorming dan de gemeenteraad en ook meer invloed kunnen uitoefenen op de voorstellen van het college. Het gevolg van de focus op het college is ook dat contacten tussen de adviesraden en de gemeenteraad gevoelig liggen, vindt de voorzitter van een Wmo-adviesraad: 'Wij zijn adviseur van het college en door het college ook ingesteld. Wij zorgen wel dat de politiek hier [de adviezen] kennis van kan nemen. Tijdens zo'n periode zullen wij ook zorgen dat wij informatie geven. Ze weten hoe wij er tegenover staan. Wij moeten wel onze plek kennen. Wij zijn geen adviesraad van de raad. Wij zorgen wel dat de raad onze adviezen kent.'

Deze positie ten opzichte van het college limiteert niet-gekozen vertegenwoordigers bovendien in de strategieën die ze kunnen hanteren om invloed uit te oefenen. Een wethouder zegt hierover: 'Ze [adviesraden] zijn een adviesraad voor het college. En dat betekent ook dat ze niet de gemeenteraad moeten adviseren, maar het college. Dus als er wat is en ze zouden dat via de pers doen, dan hebben we een probleem. Want je moet daarmee bij mij komen dat je zegt van goh, je doet iets waar ik het helemaal niet mee eens ben en ik ga de pers opzoeken. Dat zou heel raar zijn als dat gaat gebeuren.'

Ook bestaat het gevaar dat niet-gekozen vertegenwoordiging strategisch wordt gebruikt om gekozen vertegenwoordigers buitenspel te zetten. In de woorden van een wethouder: 'Want $i k$ weet nog wel dat een commissielid op een gegeven moment zei van ja, het kan toch niet zo zijn dat wij buitenspel worden gezet (...) dat u zegt alles is al besproken met de mensen in de stad om wie het gaat. Van waar blijft onze rol dan? Ja en dat zit op een heel ander vlak. En dat is, ik vind het zelf eerlijk gezegd dat je als raadslid of als raad er veel meer over na moet denken.'

Dit fenomeen is niet nieuw. Het komt ook aan de orde in discussies over de manier waarop representatieve democratie zich verhoudt tot vormen van participatieve democratie zoals interactieve beleidsvorming (zie o.a. bijdragen in Egner e.a., 2013; Mayer e.a., 2002; Forde, 2005; Schaap, 2015; VNG Denktank, 2016). Een ander problematisch aspect van de huidige vertegenwoordigingspraktijk is dat de contacten tussen niet-gekozen vertegenwoordigers en college en ambtenaren veelal informeel van aard zijn. Hetzelfde geldt voor de contacten tussen gemeenteraad en niet-gekozen vertegenwoordigers die er wel zijn. Zo maken nietgekozen vertegenwoordigers lang niet altijd gebruik van het recht op inspraak in de raad. Andersom maken gemeenteraden weinig gebruik van de mogelijkheid een hoorzitting te organiseren op het gebied van de decentralisaties. Dat de contacten tussen niet-gekozen vertegenwoordigers en college en tussen gekozen en niet-gekozen vertegenwoordigers goeddeels informeel verlopen, heeft tot gevolg dat een groot deel van de discussie plaatsvindt buiten het publieke debat. Dit publieke debat is echter van belang om vertegenwoordigingsclaims tegen het licht te houden en tegen elkaar af te kunnen wegen. 


\section{Conclusie en discussie}

Een analyse van de representatieve democratie aan de hand van het concept representative claim (Saward, 2010) brengt een gevarieerde vertegenwoordigingspraktijk in beeld. Op het gebied van de decentralisaties zijn er veel verschillende vertegenwoordigers actief. Naast gemeenteraden kunnen ook adviesraden, patiënten-, ouderen- en mantelzorgorganisaties, zorg- en welzijnsprofessionals en kerken burgers die te maken hebben met de decentralisaties vertegenwoordigen. Het is daarom belangrijk om naar het vertegenwoordigingssysteem als geheel te kijken om een uitspraak over de democratische kwaliteit in termen van gelijkheid te kunnen doen (Urbinati \& Warren, 2008; Saward, 2010; Montanaro, 2012). Op basis van deze studie concluderen we dat niet-gekozen vertegenwoordigers een belangrijke rol kunnen spelen in de representatieve democratie. Zij kunnen opkomen voor groepen die buiten beeld dreigen te raken, juist omdat zij vaak dichterbij die burgers staan. Ze kunnen zo de stem van burgers, en van de gebruikers van jeugdzorg, maatschappelijke ondersteuning, bijstand en arbeidstoeleiding in het bijzonder, laten doorklinken. Daardoor kunnen ze mogelijke ongelijkheid, die gepaard gaat met gekozen vertegenwoordiging en directe participatie, deels het hoofd bieden.

Deze studie identificeert ook mogelijkheden om gekozen en niet-gekozen vertegenwoordiging elkaar te laten versterken. Contacten tussen de twee vinden nu wel plaats maar, door de vrij eenzijdige focus van niet-gekozen vertegenwoordigers op het college, nog in beperkt mate. Als ze wel plaatsvinden, zijn deze contacten bovendien veelal informeel van aard. Door contacten tussen gekozen en nietgekozen vertegenwoordigers onderdeel te maken van het publieke debat, kan de democratische legitimiteit van beide groepen vertegenwoordigers worden versterkt. Als onderdeel van het debat zijn de claims in principe transparant voor de directe achterban en voor een breed publiek. Vertegenwoordigingsclaims kunnen zo ter discussie gesteld en verdedigd worden en als gevolg daarvan geaccepteerd of verworpen worden (vgl. Bovens, 2007). Vertegenwoordigingsclaims kunnen via lokale media publiek worden gemaakt. Bij het gebrek aan lokale media vormt echter de gemeenteraad een belangrijker forum. Niet-gekozen vertegenwoordigers kunnen zelf een punt op de raadscommissieagenda's zetten of inspreken. Gemeenteraden kunnen op hun beurt hoorzittingen organiseren. Op deze manier kunnen gemeenteraden het debat over de decentralisaties ook meer naar zich toe trekken. Hoorzittingen hebben het voordeel dat raadsleden zich onafhankelijk van het college kunnen laten informeren door een breed scala aan vertegenwoordigers. Ook kunnen hun eigen vertegenwoordigingsclaims zo worden getoetst bij andere vertegenwoordigers die goed op de hoogte zijn van de belangen van bepaalde groepen burgers. Gemeenteraden kunnen vervolgens beter de wensen en verlangens van allerlei burgers afwegen om een oordeel te vellen over de beleidsnota's en voorstellen die van het college komen. Incidenteel hebben gemeenteraden het middel van hoorzittingen al ingezet. Die ervaring leert dat er wel enige voorbereiding nodig is om het als zinvol instrument in te zetten (Bijl, 2015). Het is van belang dat gemeenteraden zelf actief de dialoog zoeken om 
gelijkheid te bevorderen, ook al achten raadsleden zich in eigen ogen voldoende benaderbaar (Cachet \& Verkaik, 2014). Hoorzittingen kunnen eveneens een manier zijn voor gemeenteraden om invulling te geven aan de oproepen hun vertegenwoordigende rol te versterken en zelfstandig van het college als verbinder tussen samenleving en overheid op te treden (Van Ostaaijen, 2016: 13ff; Paans e.a., 2016; Rob, 2016). Door gericht vertegenwoordigers van weinig gehoorde groepen uit te nodigen, kan het bovendien de gelijkheid bevorderen.

$\mathrm{Nu}$ gemeenteraden en hun leden minder kunnen terugvallen op partijen als intermediair tussen samenleving en overheid, moeten gemeenteraden als instituut dus zelf actiever worden om 'kleur te geven aan de lokale democratie' (De Graaf e.a., 2016) door andersoortige vertegenwoordigers te betrekken bij besluitvorming. Dat betekent echter niet dat het voor partijen over en uit is. Het begrip vertegenwoordigingsclaim biedt ook basis om hun representatieve functie te herzien. Voorheen waren massapartijen meer ingebed in de maatschappij, aangezien zij toen een duidelijk identificeerbare achterban hadden, zoals christenen, arbeiders etc. (Saward, 2008). Deze inbedding en afgebakende achterban maakten dat vertegenwoordigingsclaims veelal impliciet konden blijven, ze spraken immers voor zich. Dat is nu anders. Partijen hebben een minder duidelijke ideologie en kunnen niet meer rekenen op een afgebakende kiezersgroep. In plaats daarvan proberen zij nu vaak zoveel mogelijk kiezers aan te spreken (Saward, 2008). De minder duidelijke kleur en minder sterke inbedding in de maatschappij maken dat het belangrijker is geworden om de vertegenwoordigende claims die politieke partijen nog veelal impliciet maken, te expliciteren en onderdeel te maken van het publieke debat. Het expliciteren van deze claims is zowel van belang voor de geclaimde achterban als voor de andere actoren in dat debat. Daarbij moet duidelijk worden gemaakt wie partijen precies claimen te vertegenwoordigen en op basis waarvan zij dit doen.

Het expliciteren van de basis van de claims maakt ook dat het noodzakelijk is dat partijen nadenken over de responsiviteit naar hun achterban. In dit artikel hebben we de variatie in termen van autorisatie en verantwoording die vertegenwoordigers gebruiken laten zien. Autorisatie en verantwoording vinden zowel formeel (zoals verkiezingen, wetgeving, bezit van erkende expertise) als informeel (door middel van allerlei meer of minder gestructureerde contacten met de achterban) plaats. De variatie aan autorisatie- en verantwoordingsstructuren laat zien dat de institutionele positie van een actor maar een deel van het verhaal vertelt. De verschillen die bestaan in met name de autorisatiekanalen die gebruikt worden door raadsleden, laten dit zien. De aanvullende vormen, naast verkiezingen, die sommigen van hen gebruiken, zijn belangrijk om invulling te geven aan de vertegenwoordigingsrelatie. Ze zijn juist nu belangrijk, gegeven de dalende opkomsten bij verkiezingen en de dalende ledenaantallen van politieke partijen. Onze respondenten vertelden dat maar een minderheid van de gemeenteraadsleden erg actief is om in contact te komen met hun achterban. Meer onderzoek is nodig om inzicht te krijgen in hoe wijdverspreid aanvullende autorisatie en verantwoordingsstructuren daadwerkelijk zijn en welke groepen daarmee al dan niet 
in beeld komen. De beschrijving in dit artikel geeft al wel inzicht in welke activiteiten politieke partijen kunnen ondernemen om meer in contact te komen met hun achterban buiten de verkiezingstijd om.

Onze analyse van de lokale representatieve democratie laat zien dat ze levendiger en veelzijdiger is - en kan zijn - dan vaak wordt verondersteld. Niet-gekozen vertegenwoordigers kunnen een belangrijke rol in de representatieve democratie vervullen. Bovendien laat de analyse zien dat gekozen vertegenwoordigers en de politieke partijen waar ze uit voortkomen, niet zozeer een overbodig restant zijn uit het verleden zoals wel eens wordt gesuggereerd. Ze moeten wel werk verzetten om hun representatieve claim te expliciteren en inhoud te geven, willen ze relevant blijven.

\section{Literatuur}

Balinski, N. \& H.P. Young, Fair representation. Meeting the ideal of one man, one vote, Washington: 2010.

Berg, J. van den, 'De spagaat van de gedecentraliseerde eenheidsstaat', Beleid en Maatschappij, 2013/2, p. 205-220.

Bijl, J., 'Mystery burger. Zorg voor burgers', Binnenlands Bestuur 31 augustus 2015.

Boogers, M.J.G.J.A. \& L. Salomé, Gemeenteraadsverkiezingen 2014. Wie stemt wat en waarom, BMC, Den Haag: 2014.

Boogers, M.J.G.J.A., L. Schaap, D. Collignon \& N. Karsten, 'Decentralisatie als opgave', Bestuurswetenschappen, 2009/1, p. 29-49.

Bovenkamp, H.M. van de \& J.P. Vollaard, 'De democratische vertegenwoordiging van cliënten en patiënten bij de decentralisaties', Beleid en Maatschappij, 2015/2, p. 102-121.

Bovens, M.A.P., 'Analysing and assessing accountability. A conceptual framework', European Law Journal, 2007/4, p. 447-468.

Bovens, M.A.P. \& A.C. Wille, Diplomademocratie. Over de spanning tussen meritocratie en democratie, Amsterdam: 2011.

Cachet, A. \& N. Verkaik, Aanzien of afzien? Een essay over het aanzien van het raadslidmaatschap, OBMC Consulting, Den Haag: 2014 (in opdracht van Raadslid.nu).

Commissie Toekomstgericht Lokaal Bestuur, Op weg naar meervoudige democratie, VNG, Den Haag: 2016.

Dekker, P., J. den Ridder, P. van Houwelingen \& S. Kooiker, Zorg en onbehagen bij het grote publiek, essay geschreven voor de conferentie 'Tien jaar zorgstelsel: Klaar voor de toekomst' op 10 oktober 2016 (in opdracht van de Raad voor de Volksgezondheid en Samenleving).

Denters, S.A.H., Controle en verantwoording in een veranderend lokaal bestuur, Enschede: 2015 (in opdracht van Raadslid.nu).

Denters, S.A.H. \& M.J.G.J.A. Boogers, 'Lokale democratie doorgelicht. Inleiding', Bestuurswetenschappen 2016/4, p. 18-26.

Egner, B., D. Sweeting \& P.J. Klok (eds.), Local councillors in Europe, Wiesbaden: 2013.

Forde, C., 'Participatory democracy or pseudo-participation? Local government reform in Ireland', Local Government Studies, 2005/2, p. 137-148.

Fraanje, R., Sturen in dienstbaarheid. Verkennend essay naar de rollen van de gemeenteraad bij de uitvoering van de nieuwe taken in het sociaal domein, Den Haag: 2015 (in opdracht van Raadslid.nu). 
Graaf, L.J. de, L. Schaap \& M. Theuns, Raadswerk is maatwerk. Hoe kun je als raad(slid) meer kleur geven aan de lokale democratie?, Tilburg: 2016 (in opdracht van Raadslid.nu).

Irwin, G. \& J. van Holsteyn, 'De kloof tussen burger en bestuur', J. van Holsteyn \&

C. Mudde (eds.), Democratie in verval?, Amsterdam: 2002, p. 33-50.

Jager-de Lange, A. de, B.J. Flos \& B. van Rens, Nationaal raadsledenonderzoek 2014, Nijmegen: 2014 (Daadkracht in samenwerking met Raadslid.nu).

Karlsson, S., 'Who do the local councillors of Europe represent?', B. Egner, D. Sweeting \& P.J. Klok (eds.), Local councillors in Europe, Wiesbaden: 2013, p. 97-120.

Lange, S. de, M. Leyenaar \& P. de Jong, Partijen: overbodig of nodig?, Raad voor het openbaar bestuur, Den Haag: 2012.

Loots, J. \& P.H. Peeters, De gemeenteraad heeft geen toekomst, Eindhoven: 2013.

Maia, R.C.M., 'Non-electoral political representation. Expanding discursive domains', Representation, 2012/4, p. 429-443.

Mair, P., Democracy beyond parties, Center for the Study of Democracy, Irvine, CA: 2005.

Mayer, I., J. Edelenbos \& R. Monnikhof, 'Stormram of stut? Democratische dilemma's van interactieve beleidsontwikkeling', J. van Holsteyn \& C. Mudde (eds.), Democratie in verval?, Amsterdam: 2002, p. 83-104.

Michels, A.M.B. \& H. Binnema, 'Hoe divers, invloedrijk en deliberatief is een G1000? Het ontwerp van een burgertop en de verwezenlijking van democratische waarden', Bestuurswetenschappen, 2016/1, p. 17-36.

Ministerie van Binnenlandse Zaken en Koninkrijksrelaties (BZK), Agenda lokale democratie, Den Haag: 2015.

Montanaro, L., 'The democratic legitimacy of self-appointed representatives', The Journal of Politics, 2012/4, p. 1094-1107.

Ostaaijen, J.J.C. van, Hard naar het college, zacht naar de samenleving. Op zoek naar een verbindende rol van de gemeenteraad, Tilburg: 2016.

Paans, J., J.D. Pruim \& M. van Omme, Gemeenteraadsleden, vertegenwoordig meer! Pleidooi voor de herwaardering van tegenwicht en tegenspraak, Den Haag: 2016 (in opdracht van Raadslid.nu).

Peters K., V.P. van Stipdonk \& P.G. Castenmiller, Verkenning van lokale democratie in Nederland, Den Haag: 2014 (in opdracht van het Ministerie van BZK).

Peters, K. \& V.P. van Stipdonk, 'Hoe staat de lokale democratie in Nederland ervoor?', Bestuurswetenschappen, 2016/4, p. 27-49.

Pitkin, H.F., The concept of representation, Berkeley, CA: 1967.

Raad voor het openbaar bestuur (Rob), Loslaten in vertrouwen. Naar een nieuwe verhouding tussen overheid, markt én samenleving, Den Haag: 2012.

Raad voor het openbaar bestuur (Rob), Reactie op decentralisatiebrief dhr. Plasterk 23 april, Den Haag: 2013.

Raad voor het openbaar bestuur (Rob), 15,9 uur. De verbindende rol van het raadslid in een vitale democratie, Den Haag: 2016.

Ridder, J. den, Schakels of obstakels? Nederlandse politieke partijen en de eensgezindheid, verdeeldheid en representativiteit van partijleden, proefschrift Universiteit Leiden, Leiden: 2014.

Ridder, J. den \& P. Dekker, Meer democratie, minder politiek? Een studie van de publieke opinie in Nederland, Sociaal en Cultureel Planbureau, Den Haag: 2015.

Rehfeld, A., 'Towards a general theory of political representation', The Journal of Politics, 2006/1, p. 1-21.

Saward, M., 'Making representations. Modes and strategies of political parties', European Review, 2008/3, p. 271-286. 
Saward, M., 'Authorisation and authenticity. Representation and the unelected', The Journal of Political Philosophy, 2009/1, p. 1-22.

Saward, M., The representative claim, Oxford: 2010.

Schaap, L., Lokaal bestuur, Dordrecht: 2015.

Severs, E., 'Representation as claims-making. Quid responsiveness?', Representation, 2010/4, p. 411-423.

Sociaal en Cultureel Planbureau (SCP), De sociale staat van Nederland 2015, Den Haag: 2015.

Staatscommissie-Elzinga, Dualisme en lokale democratie, Den Haag: 2000.

Stimuleringsfonds voor de Pers, Meer nieuwsaanbod, meer van het zelfde nieuws. De positie van nieuwsvoorziening in de regio anno 2012: een algemene aanbodsanalyse, Den Haag: 2012.

Tonkens, E., M. Trappenburg, M. Hurenkamp \& J. Schmidt, Montessoridemocratie. Spanningen tussen burgerparticipatie en de lokale politiek, Amsterdam: 2015.

Urbinati, N. \& W.E. Warren, 'The concept of representation in contemporary democratic theory', Annual Review of Political Science, 2008/1, p. 387-412.

Veldheer, V., J. Jonker, L. van Noije \& C. Vrooman, Een beroep op de burger. Minder verzorgingsstaat, meer eigen verantwoordelijkheid?, Sociaal en Cultureel Planbureau, Den Haag: 2012.

VNG Denktank, Maatwerkdemocratie. Naar een krachtiger, trefzekere gemeenteraad 2020 als kruispunt in de lokale democratie, jaarbericht 2016, VNG, Den Haag: 2016.

Wilde, P. de, 'Representative claims analysis. Theory meets method', Journal of European Public Policy, 2013/2, p. 278-294.

Wolff, C., Functional representation and democracy in the EU, Colchester: 2013.

Zee, F. van der, Een goede raad? Een analyse van de aanbevelingen van de commissie-Elzinga en de Wet Dualisering Gemeentebestuur met betrekking tot de volksvertegenwoordigende functie van het raadslid, masterthesis Universiteit Leiden, Leiden: 2013. 